UDC 621.87

\title{
MATHEMATICAL MODEL OF THE DYNAMICS CHANGE DEPARTURE OF THE JIB SYSTEM MANIPULATOR WITH THE SIMULTANEOUS MOVEMENT OF ITS LINKS
}

\author{
V.S. Loveikin ${ }^{1}$, \\ Yu.O. Romasevych ${ }^{1}$, \\ O.O. Spodoba ${ }^{1}$, \\ A.V. Loveikin ${ }^{2}$, \\ K.I. Pochka ${ }^{3}$ \\ ${ }^{1}$ National University of Life and Environmental Sciences of Ukraine \\ ${ }^{2}$ Taras Shevchenko National University of Kyiv \\ ${ }^{3}$ Kyiv National University of Construction and Architecture
}

DOI: $10.32347 / 2410-2547.2020 .104 .175-190$

An equation of motion of the manipulator is obtained taking into account the influence of the inertial component of each link of the boom system and the effect of the oscillatory movement of the cargo on the dynamic loads of the metalware elements and hydraulic drive elements. The influence of the simultaneous movement of the first jib section, the second jib section and the telescopic jib section on cargo oscillation, as well as the effect of cargo oscillation on dynamic loads that occur in the boom system and manipulator hydraulic drive elements, is determined.

Keywords: mathematical model, varying the radius, combination of movements, manipulator, Lagrange equations of the second kind, dynamic loads, load oscillations.

\section{Introduction}

During the process of unloading and loading operations in the elements of the boom system and the elements of the drive of the manipulator considerable dynamic loads occur. These loads are the result of the oscillatory movement of the load and the uneven rotation of the boom system with the uniform movement of the rods of the hydraulic cylinders [1-2]. Dynamic loads depend on the kinematic parameters of the manipulator and the nature of the speed of movement of the links of the boom system with the cargo. According to the normative-technical documentation, which regulates the operation of manipulators, it is allowed to combine operations of simultaneous movement of several links of the boom system. Combining the operations of the simultaneous movement of the links of the boom system can significantly reduce the dynamic loads and accordingly increase the performance, reliability of the elements of the boom system and the hydraulic equipment of the manipulator. To determine the actual dynamic loads in the elements of the design of the manipulator when combined movements of the links of the boom system, it is necessary to have adequate mathematical models [3-8].

(C) Loveikin V.S., Romasevich Yu.O., Spodoba O.O., Loveykin A.V., Pochka K.I. 


\section{Analysis of publications}

Known [3-11] methods for constructing a mathematical model of the manipulator. In these works, the boom system of the manipulator is presented as a holonomic mechanical system in which the centres of gravity of the links of the metal structure coincides with their geometrical parameters. The mathematical model of the manipulator is considered, the relation between the kinematic dependences of the drive link of the manipulator and the load. The influence of dynamic loads on the elements of metalwork of the boom system of the manipulator is analyzed. In the papers [12-15], an analysis of the solution of optimization problems for reducing load oscillations is considered. The analysis of the influence of dynamic loads on the elements of the boom system and the hydraulic drive is considered in the papers [16-19]. With a large amount of consideration of the problem of dynamic analysis of the combination of simultaneous movement of the links of the boom system, the solution of this problem for manipulators with hydraulic drive is not considered taking into account the load fluctuations at the end of the boom system.

\section{Purpose and research task statement}

The purpose of this work is to build a mathematical model of the dynamics of change of departure of the boom system of the manipulator when combining operations of simultaneous movement of the first jib section, movement of the second jib section and movement of the telescopic jib section with cargo oscillation at the end of the boom system.

\section{Research results}

When investigating the dynamics of change of departure of the boom system of the manipulator with simultaneous movement of the first jib section, movement of the second jib section, moving the telescopic jib section and the cargo oscillations, we accept the following assumptions:

- we believe that all links in the boom system are perfectly rigid except for the cargo, which oscillates in the plane of change of departure;

- semi-dry friction in moving elements of eye joint and viscous friction of fluid in pipelines is not taken into account;

- the compressibility of the working fluid in the elements of the hydraulic drive is not taken into account.

Based on the above assumptions, the boom system of the manipulator in the process of changing the departure of the cargo with the combination of the three main movements and oscillates of the cargo is presented as a holonomic mechanical system with four degrees of freedom. The angular and linear coordinates of the moving of the first jib section, the second jib section and the telescopic jib section are calculated from the $x$ axis, and the angular coordinate of the cargo deviation from the $y$ axis, (Fig. 1). For the generalized coordinates of the boom system we take the angular coordinates: rotate the first jib section, rotate the second jib section, the linear coordinate of movement of the telescopic jib section, and the vertical deviation of the cargo (Fig. 1). 


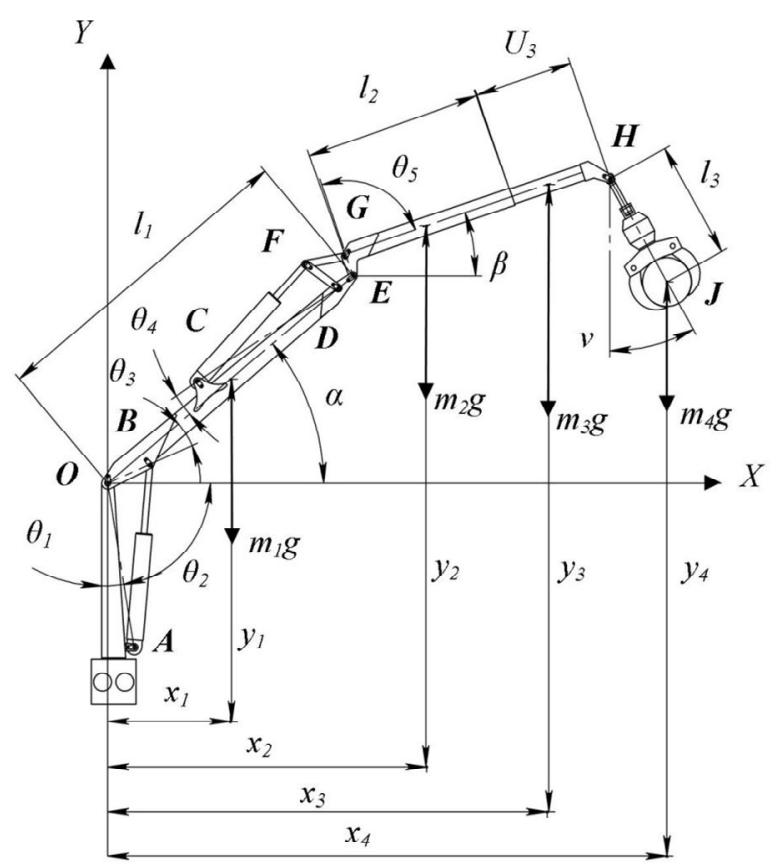

Fig. 1. Dynamic model of boom system of the manipulator

In Fig. 1 accepted the following designations: $l_{1}-$ length of the first jib section; $l_{2}$ - length of the second jib section; $l_{3}$ - the length of the suspension; $m_{1}, m_{2}, m_{3}, m_{4}$ - weight respectively of the first boom section, the second boom section, the telescopic section and the cargo; $\theta_{1}, \theta_{2}, \theta_{3}, \theta_{4}, \theta_{5}$ - angles formed by the geometrical parameters of the elements of the boom system and the hydraulic cylinders of the manipulator; $x_{1}, x_{2}, x_{3}, x_{4}$ - horizontal coordinates of the centers of mass of the first jib section, the second jib section, the telescopic jib section and the cargo; $y_{1}, y_{2}, y_{3}, y_{4}$ - vertical coordinates of the centers of mass of the first jib section, the second jib section, the telescopic jib section and the cargo.

Expressed of the coordinates of the centres of mass for the first jib section, the second jib section, the telescopic jib section and the cargo in the generalized coordinates:

$$
\left\{\begin{array}{l}
x_{1}=\frac{l_{1}}{2} \cos (\alpha) ; \\
y_{1}=\frac{l_{1}}{2} \sin (\alpha) ;
\end{array}\right.
$$




$$
\begin{gathered}
\left\{\begin{array}{l}
x_{2}=l_{1} \cdot \cos (\alpha)+\frac{l_{2}}{2} \cdot \cos (\beta) ; \\
y_{2}=l_{1} \cdot \sin (\alpha)+\frac{l_{2}}{2} \cdot \sin (\beta) ;
\end{array}\right. \\
\left\{\begin{array}{l}
x_{3}=l_{1} \cdot \cos (\alpha)+\left(\frac{l_{2}}{2}+U_{3}\right) \cdot \cos (\beta)+l_{3} \cdot \sin (v) ; \\
y_{3}=l_{1} \cdot \sin (\alpha)+\left(\frac{l_{2}}{2}+U_{3}\right) \cdot \sin (\beta)-l_{3} \cdot \cos (v),
\end{array}\right. \\
\left\{\begin{array}{l}
x_{4}=l_{1} \cdot \cos (\alpha)+\left(l_{2}+U_{3}\right) \cdot \cos (\beta)+l_{3} \cdot \sin (v) ; \\
y_{4}=l_{1} \cdot \sin (\alpha)+\left(l_{2}+U_{3}\right) \cdot \sin (\beta)-l_{3} \cdot \cos (v) .
\end{array}\right.
\end{gathered}
$$

To compile the equations of motion of the manipulator in the process of changing the departure of the boom system with the cargo, while simultaneously moving the first jib section, the second jib section, the telescopic jib section and the cargo, we use the second-order Lagrange equations, which for the system shown in Fig. 1, have the form:

$$
\left\{\begin{array}{l}
\frac{d}{d t} \frac{\partial T}{\partial \dot{\alpha}}-\frac{\partial T}{\partial \alpha}=Q_{\alpha}-\frac{\partial V}{\partial \alpha} \\
\frac{d}{d t} \frac{\partial T}{\partial \dot{\beta}}-\frac{\partial T}{\partial \beta}=Q_{\beta}-\frac{\partial V}{\partial \beta} \\
\frac{d}{d t} \frac{\partial T}{\partial \dot{U}_{3}}-\frac{\partial T}{\partial U_{3}}=Q_{U_{3}}-\frac{\partial V}{\partial U_{3}} \\
\frac{d}{d t} \frac{\partial T}{\partial \dot{v}}-\frac{\partial T}{\partial v}=Q_{v}-\frac{\partial V}{\partial v}
\end{array}\right.
$$

where: $t$ - time; $T, V$ - respectively, the kinetic and potential energy of the boom system of the manipulator; $Q_{\alpha}, Q_{\beta}, Q_{U_{3}}, Q_{v}$ - non-conservative components of the generalized forces of the system corresponding to the generalized coordinates $\alpha, \beta, U_{3}, \nu$. form:

Then the kinetic energy of the boom system of the manipulator will take the

$$
\begin{gathered}
T=\frac{1}{2} \cdot J_{1} \cdot \dot{\alpha}^{2}+\frac{1}{2} \cdot m_{2} \cdot\left(\dot{x}_{2}^{2}+\dot{y}_{2}^{2}\right)+\frac{1}{2} \cdot J_{2} \cdot \dot{\beta}^{2}+\frac{1}{2} \cdot m_{3} \cdot\left(\dot{x}_{3}^{2}+\dot{y}_{3}^{2}\right)+ \\
+\frac{1}{2} \cdot J_{3} \cdot \dot{\beta}^{2}+\frac{1}{2} \cdot m_{4} \cdot\left(\dot{x}_{4}^{2}+\dot{y}_{4}^{2}\right),
\end{gathered}
$$

where: $m_{2}, m_{3}, m_{4}$ - the masses respectively of the second jib section, the telescopic jib section and the cargo; $J_{1}, J_{2}, J_{3}$ - moments of inertia respectively of the first jib section, the second jib section and the telescopic jib section (Fig. 1).

The potential energy of the boom system of the manipulator in the process of change of departure will be as follows:

$$
V=\left(m_{1} y_{1}+m_{2} y_{2}+m_{3} y_{3}+m_{4} y_{4}\right) \cdot g
$$


where $g$ - free fall acceleration.

Take the derivatives of kinetic energy (5) that are included in the system of equations (4):

$$
\begin{aligned}
& \frac{\partial T}{\partial \alpha}=m_{2}\left(\dot{x}_{2} \frac{\partial \dot{x}_{2}}{\partial \alpha}+\dot{y}_{2} \frac{\partial \dot{y}_{2}}{\partial \alpha}\right)+m_{3}\left(\dot{x}_{3} \frac{\partial \dot{x}_{3}}{\partial \alpha}+\dot{y}_{3} \frac{\partial \dot{y}_{3}}{\partial \alpha}\right)+m_{4}\left(\dot{x}_{4} \frac{\partial \dot{x}_{4}}{\partial \alpha}+\dot{y}_{4} \frac{\partial \dot{y}_{4}}{\partial \alpha}\right) ; \\
& \frac{\partial T}{\partial \beta}=m_{2}\left(\dot{x}_{2} \frac{\partial \dot{x}_{2}}{\partial \beta}+\dot{y}_{2} \frac{\partial \dot{y}_{2}}{\partial \beta}\right)+m_{3}\left(\dot{x}_{3} \frac{\partial \dot{x}_{3}}{\partial \beta}+\dot{y}_{3} \frac{\partial \dot{y}_{3}}{\partial \beta}\right)+m_{4}\left(\dot{x}_{4} \frac{\partial \dot{x}_{4}}{\partial \beta}+\dot{y}_{4} \frac{\partial \dot{y}_{4}}{\partial \beta}\right) ; \\
& \frac{\partial T}{\partial U_{3}}=m_{2}\left(\dot{x}_{2} \frac{\partial \dot{x}_{2}}{\partial U_{3}}+\dot{y}_{2} \frac{\partial \dot{y}_{2}}{\partial U_{3}}\right)+m_{3}\left(\dot{x}_{3} \frac{\partial \dot{x}_{3}}{\partial U_{3}}+\dot{y}_{3} \frac{\partial \dot{y}_{3}}{\partial U_{3}}\right)+m_{4}\left(\dot{x}_{4} \frac{\partial \dot{x}_{4}}{\partial U_{3}}+\dot{y}_{4} \frac{\partial \dot{y}_{4}}{\partial U_{3}}\right) ; \\
& \frac{\partial T}{\partial v}=m_{2}\left(\dot{x}_{2} \frac{\partial \dot{x}_{2}}{\partial v}+\dot{y}_{2} \frac{\partial \dot{y}_{2}}{\partial v}\right)+m_{3}\left(\dot{x}_{3} \frac{\partial \dot{x}_{3}}{\partial v}+\dot{y}_{3} \frac{\partial \dot{y}_{3}}{\partial v}\right)+m_{4}\left(\dot{x}_{4} \frac{\partial \dot{x}_{4}}{\partial v}+\dot{y}_{4} \frac{\partial \dot{y}_{4}}{\partial v}\right) ; \\
& \frac{\partial T}{\partial \dot{\alpha}}=J_{1} \cdot \dot{\alpha}+m_{2}\left(\dot{x}_{2} \frac{\partial x_{2}}{\partial \alpha}+\dot{y}_{2} \frac{\partial y_{2}}{\partial \alpha}\right)+m_{3}\left(\dot{x}_{3} \frac{\partial \dot{x}_{3}}{\partial \alpha}+\dot{y}_{3} \frac{\partial \dot{y}_{3}}{\partial \alpha}\right)+m_{4}\left(\dot{x}_{4} \frac{\partial \dot{x}_{4}}{\partial \alpha}+\dot{y}_{4} \frac{\partial \dot{y}_{4}}{\partial \alpha}\right) ; \\
& \frac{\partial T}{\partial \dot{\beta}}=\left(J_{2}+J_{3}\right) \cdot \dot{\beta}+m_{2}\left(\dot{x}_{2} \frac{\partial x_{2}}{\partial \beta}+\dot{y}_{2} \frac{\partial y_{2}}{\partial \beta}\right)+m_{3}\left(\dot{x}_{3} \frac{\partial \dot{x}_{3}}{\partial \beta}+\dot{y}_{3} \frac{\partial \dot{y}_{3}}{\partial \beta}\right)+m_{4}\left(\dot{x}_{4} \frac{\partial \dot{x}_{4}}{\partial \beta}+\dot{y}_{4} \frac{\partial \dot{y}_{4}}{\partial \beta}\right) \text {; } \\
& \frac{\partial T}{\partial \dot{U}_{3}}=m_{2}\left(\dot{x}_{2} \frac{\partial x_{2}}{\partial U_{3}}+\dot{y}_{2} \frac{\partial y_{2}}{\partial U_{3}}\right)+m_{3}\left(\dot{x}_{3} \frac{\partial \dot{x}_{3}}{\partial U_{3}}+\dot{y}_{3} \frac{\partial \dot{y}_{3}}{\partial U_{3}}\right)+m_{4}\left(\dot{x}_{4} \frac{\partial \dot{x}_{4}}{\partial U_{3}}+\dot{y}_{4} \frac{\partial \dot{y}_{4}}{\partial U_{3}}\right) \text {; } \\
& \frac{\partial T}{\partial \dot{v}}=m_{2}\left(\dot{x}_{2} \frac{\partial \dot{x}_{2}}{\partial v}+\dot{y}_{2} \frac{\partial \dot{y}_{2}}{\partial v}\right)+m_{3}\left(\dot{x}_{3} \frac{\partial \dot{x}_{3}}{\partial v}+\dot{y}_{3} \frac{\partial \dot{y}_{3}}{\partial v}\right)+m_{4}\left(\dot{x}_{4} \frac{\partial \dot{x}_{4}}{\partial v}+\dot{y}_{4} \frac{\partial \dot{y}_{4}}{\partial v}\right) \text {; } \\
& \frac{d}{d t} \frac{\partial T}{\partial \dot{\alpha}}=J_{1} \cdot \ddot{\alpha}+m_{2}\left(\ddot{x}_{2} \frac{\partial x_{2}}{\partial \alpha}+\dot{x}_{2} \frac{\partial \dot{x}_{2}}{\partial \alpha}+\ddot{y}_{2} \frac{\partial y_{2}}{\partial \alpha}+\dot{y}_{2} \frac{\partial \dot{y}_{2}}{\partial \alpha}\right)+ \\
& +m_{3}\left(\ddot{x}_{3} \frac{\partial x_{3}}{\partial \alpha}+\dot{x}_{3} \frac{\partial \dot{x}_{3}}{\partial \alpha}+\ddot{y}_{3} \frac{\partial y_{3}}{\partial \alpha}+\dot{y}_{3} \frac{\partial \dot{y}_{3}}{\partial \alpha}\right)+m_{4}\left(\ddot{x}_{4} \frac{\partial x_{4}}{\partial \alpha}+\dot{x}_{4} \frac{\partial \dot{x}_{4}}{\partial \alpha}+\ddot{y}_{4} \frac{\partial y_{4}}{\partial \alpha}+\dot{y}_{4} \frac{\partial \dot{y}_{4}}{\partial \alpha}\right) ; \\
& \frac{d}{d t} \frac{\partial T}{\partial \dot{\beta}}=\left(J_{2}+J_{3}\right) \cdot \ddot{\beta}+m_{2}\left(\ddot{x}_{2} \frac{\partial x_{2}}{\partial \beta}+\dot{x}_{2} \frac{\partial \dot{x}_{2}}{\partial \beta}+\ddot{y}_{2} \frac{\partial y_{2}}{\partial \beta}+\dot{y}_{2} \frac{\partial \dot{y}_{2}}{\partial \beta}\right)+ \\
& +m_{3}\left(\ddot{x}_{3} \frac{\partial x_{3}}{\partial \beta}+\dot{x}_{3} \frac{\partial \dot{x}_{3}}{\partial \beta}+\ddot{y}_{3} \frac{\partial y_{3}}{\partial \beta}+\dot{y}_{3} \frac{\partial \dot{y}_{3}}{\partial \beta}\right)+m_{4}\left(\ddot{x}_{4} \frac{\partial x_{4}}{\partial \beta}+\dot{x}_{4} \frac{\partial \dot{x}_{4}}{\partial \beta}+\ddot{y}_{4} \frac{\partial y_{4}}{\partial \beta}+\dot{y}_{4} \frac{\partial \dot{y}_{4}}{\partial \beta}\right) ; \\
& \frac{d}{d t} \frac{\partial T}{\partial \dot{U}_{3}}=m_{2}\left(\ddot{x}_{2} \frac{\partial x_{2}}{\partial U_{3}}+\dot{x}_{2} \frac{\partial \dot{x}_{2}}{\partial U_{3}}+\ddot{y}_{2} \frac{\partial y_{2}}{\partial U_{3}}+\dot{y}_{2} \frac{\partial \dot{y}_{2}}{\partial U_{3}}\right)+m_{3}\left(\ddot{x}_{3} \frac{\partial x_{3}}{\partial U_{3}}+\dot{x}_{3} \frac{\partial \dot{x}_{3}}{\partial U_{3}}+\right. \\
& \left.+\ddot{y}_{3} \frac{\partial y_{3}}{\partial U_{3}}+\dot{y}_{3} \frac{\partial \dot{y}_{3}}{\partial U_{3}}\right)+m_{4}\left(\ddot{x}_{4} \frac{\partial x_{4}}{\partial U_{3}}+\dot{x}_{4} \frac{\partial \dot{x}_{4}}{\partial U_{3}}+\ddot{y}_{4} \frac{\partial y_{4}}{\partial U_{3}}+\dot{y}_{4} \frac{\partial \dot{y}_{4}}{\partial U_{3}}\right) ; \\
& \frac{d}{d t} \frac{\partial T}{\partial \dot{v}}=m_{2}\left(\ddot{x}_{2} \frac{\partial x_{2}}{\partial v}+\dot{x}_{2} \frac{\partial \dot{x}_{2}}{\partial v}+\ddot{y}_{2} \frac{\partial y_{2}}{\partial v}+\dot{y}_{2} \frac{\partial \dot{y}_{2}}{\partial v}\right)+m_{3}\left(\ddot{x}_{3} \frac{\partial x_{3}}{\partial v}+\dot{x}_{3} \frac{\partial \dot{x}_{3}}{\partial v}+\right. \\
& \left.+\ddot{y}_{3} \frac{\partial y_{3}}{\partial v}+\dot{y}_{3} \frac{\partial \dot{y}_{3}}{\partial v}\right)+m_{4}\left(\ddot{x}_{4} \frac{\partial x_{4}}{\partial v}+\dot{x}_{4} \frac{\partial \dot{x}_{4}}{\partial v}+\ddot{y}_{4} \frac{\partial y_{4}}{\partial v}+\dot{y}_{4} \frac{\partial \dot{y}_{4}}{\partial v}\right) \text {. }
\end{aligned}
$$


Take partial derivatives of potential energy (6):

$$
\begin{gathered}
\frac{\partial V}{\partial \beta}=\left(m_{2} \frac{\partial y_{2}}{\partial \beta}+m_{3} \frac{\partial y_{3}}{\partial \beta}+m_{4} \frac{\partial y_{4}}{\partial \beta}\right) g \\
\frac{\partial V}{\partial \alpha}=\left(m_{1} \frac{\partial y_{1}}{\partial \alpha}+m_{2} \frac{\partial y_{2}}{\partial \alpha}+m_{3} \frac{\partial y_{3}}{\partial \alpha}+m_{4} \frac{\partial y_{4}}{\partial \alpha}\right) g ; \\
\frac{\partial V}{\partial U_{3}}=\left(m_{3} \frac{\partial y_{3}}{\partial U_{3}}+m_{4} \frac{\partial y_{4}}{\partial U_{3}}\right) g ; \\
\frac{\partial V}{\partial v}=m_{4} \frac{\partial y_{4}}{\partial v} \cdot g .
\end{gathered}
$$

The variation of the displacement of the rods of the hydraulic cylinders is expressed by the variation of the generalized coordinates:

$$
\begin{gathered}
Q_{\alpha}=F_{1} \frac{\partial U_{1}}{\partial \alpha}+F_{2} \frac{\partial U_{2}}{\partial \alpha} ; \\
Q_{\beta}=F_{2} \frac{\partial U_{2}}{\partial \beta} ; \\
Q_{U_{3}}=F_{3} .
\end{gathered}
$$

where: $F_{1}$ - efforts in lifting the first jib section; $F_{2}$ - efforts in the hydraulic cylinder of the second jib section; $F_{3}$ - efforts in the hydraulic cylinder to move the telescopic jib section.

Substituting expressions (7 - 9) into the system of equations (4), we obtain a system of differential equations of motion of the manipulator in the process of changing the departure of the boom system with the cargo when the three main motions of the boom system are combined:

$$
\left\{\begin{array}{l}
J_{1} \ddot{\alpha}+m_{2}\left(\ddot{x}_{2} \frac{\partial x_{2}}{\partial \alpha}+\ddot{y}_{2} \frac{\partial y_{2}}{\partial \alpha}\right)+m_{3}\left(\ddot{x}_{3} \frac{\partial x_{3}}{\partial \alpha}+\ddot{y}_{3} \frac{\partial y_{3}}{\partial \alpha}\right)+m_{4}\left(\ddot{x}_{4} \frac{\partial x_{4}}{\partial \alpha}+\right. \\
\left.+\ddot{y}_{4} \frac{\partial y_{4}}{\partial \alpha}\right)=F_{1} \frac{\partial U_{1}}{\partial \alpha}+F_{2} \frac{\partial U_{2}}{\partial \alpha}-\left(m_{1} \frac{\partial y_{1}}{\partial \alpha}+m_{2} \frac{\partial y_{2}}{\partial \alpha}+m_{3} \frac{\partial y_{3}}{\partial \alpha}+m_{4} \frac{\partial y_{4}}{\partial \alpha}\right) g ; \\
\left(J_{2}+J_{2}\right) \ddot{\beta}+m_{2}\left(\ddot{x}_{2} \frac{\partial x_{2}}{\partial \beta}+\ddot{y}_{2} \frac{\partial y_{2}}{\partial \beta}\right)++m_{3}\left(\ddot{x}_{3} \frac{\partial x_{3}}{\partial \beta}+\ddot{y}_{3} \frac{\partial y_{3}}{\partial \beta}\right)+ \\
+m_{4}\left(\ddot{x}_{4} \frac{\partial x_{4}}{\partial \beta}+\ddot{y}_{4} \frac{\partial y_{4}}{\partial \beta}\right)=-F_{2} \frac{\partial U_{2}}{\partial \beta}-\left(m_{2} \frac{\partial y_{2}}{\partial \beta}+m_{3} \frac{\partial y_{3}}{\partial \beta}+m_{4} \frac{\partial y_{4}}{\partial \beta}\right) g ; \\
m_{3}\left(\ddot{x}_{3} \frac{\partial x_{3}}{\partial U_{3}}+\ddot{y}_{3} \frac{\partial y_{3}}{\partial U_{3}}\right)+m_{4}\left(\ddot{x}_{4} \frac{\partial x_{4}}{\partial U_{3}}+\ddot{y}_{4} \frac{\partial y_{4}}{\partial U_{3}}\right)=-F_{3}-\left(m_{3} \frac{\partial y_{3}}{\partial U_{3}}+m_{4} \frac{\partial y_{4}}{\partial U_{3}}\right) g ; \\
m_{4}\left(\ddot{x}_{4} \frac{\partial x_{4}}{\partial v}+\ddot{y}_{4} \frac{\partial y_{4}}{\partial v}\right)=-m_{4} \frac{\partial y_{4}}{\partial v} g .
\end{array}\right.
$$

Find the coordinates of the driving mechanisms that are part of the system of equations (11). 


$$
\begin{aligned}
& A B=U_{1}=\sqrt{A O^{2}+O B^{2}-2 \cdot A O \cdot O B \cdot \cos \left(\theta_{2}+\alpha-\theta_{3}\right)} . \\
& C F=U_{2}=\sqrt{C D^{2}+D F^{2}-2 \cdot C D \cdot D F \cdot \cos (\angle C D F)} .
\end{aligned}
$$

To determine, $\angle C D F$ first consider the four link mechanism $E D F G$ (Fig. 2), and define the diagonal $D G$ :

$$
\begin{gathered}
D G=\sqrt{E G^{2}+D E^{2}-2 \cdot E G \cdot D E \cdot \cos (\angle D E G)} . \\
\angle D E G=\pi-\left(\theta_{5}+\beta-\alpha\right) .
\end{gathered}
$$

After substitution of expression (13) in dependence (14) we obtain:

$$
D G=\sqrt{E G^{2}+D E^{2}-2 \cdot E G \cdot D E \cdot \cos \left(\theta_{5}+\beta-\alpha\right)} .
$$

Using the sine theorem, we write:

$$
\frac{\operatorname{Sin} \angle D E G}{D G}=\frac{\operatorname{Sin} \angle E D G}{E G} .
$$

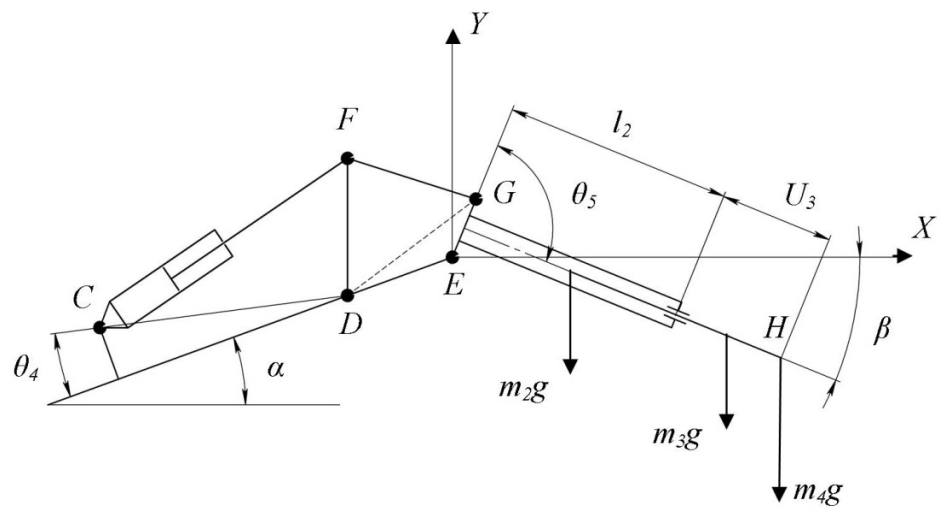

Fig. 2. The kinematic scheme of the drive of the second jib section

From equation (16) we find:

$$
\angle A D E=\operatorname{ArcSin}\left(\frac{E G \cdot \sin \left(\theta_{5}+\beta-\alpha\right)}{D G}\right) .
$$

We find the angle $\angle F D G$ from the expression:

$$
F G^{2}=D F^{2}+D G^{2}-2 \cdot D F \cdot D G \cdot \cos \angle F D G .
$$

Then:

$$
\angle F D G=\arccos \left(\frac{D G^{2}+D F^{2}-F G^{2}}{2 \cdot D F \cdot D G}\right) .
$$

Adding expressions (18) and (20), we find the angle $\angle E D F$ :

$$
\angle E D F=\arcsin \left(\frac{E G \cdot \sin \left(\theta_{5}+\beta-\alpha\right)}{D G}\right)+\arccos \left(\frac{D G^{2}+D F^{2}-F G^{2}}{2 \cdot D F \cdot D G}\right) .
$$

Now can find the angle $\angle C D F$ : 


$$
\angle C D F=\pi-\angle E D F-\theta_{4} .
$$

After substitution of expression (21) in dependence (12) we obtain:

$$
U_{2}=\sqrt{C D^{2}+D F^{2}+2 \cdot C D \cdot D F \cdot \cos \left(\angle E D F-\theta_{4}\right)} .
$$

To move the links of the boom system, hydraulic cylinders develop driving forces, which are determined by mechanical characteristics.

The characteristics are presented in the form of quadratic relationships between the acting forces and the displacement rates of the rods of the hydraulic cylinders:

$$
\begin{gathered}
F_{1}=P_{n} \cdot A_{1} \cdot \sqrt{1-\frac{A_{1} \cdot \dot{U}_{1}}{Q_{1}}}, \\
F_{2}=P_{n} \cdot A_{2} \cdot \sqrt{1-\frac{A_{2} \cdot \dot{U}_{2}}{Q_{2}}}, \\
F_{3}=P_{n} \cdot A_{3} \cdot \sqrt{1-\frac{A_{3} \cdot \dot{U}_{3}}{Q_{3}}},
\end{gathered}
$$

where: $P_{n}$ - fluid pressure in the hydraulic system; $A_{1}, A_{2}, A_{3}$ - respectively, the piston area of the hydraulic cylinders of the first jib section, the second jib section and the telescopic jib section; $\dot{U}_{1}, \dot{U}_{2}, \dot{U}_{3}$ according the speed of the cylinder rods of the first jib section, the second jib section and the telescopic section. The flow of the working fluid flowing through the hydraulic distributor to provide the hydraulic cylinders with the required start mode and speed of movement of the boom system is determined by the following dependencies, respectively, for the hydraulic cylinder of the first jib section, the second jib section and the telescopic jib section:

$$
\begin{aligned}
& Q_{1}=\mu \cdot f_{1} \cdot \sqrt{\frac{2 \cdot \Delta P_{1}}{\rho}} ; \\
& Q_{2}=\mu \cdot f_{2} \cdot \sqrt{\frac{2 \cdot \Delta P_{2}}{\rho}} ; \\
& Q_{3}=\mu \cdot f_{3} \cdot \sqrt{\frac{2 \cdot \Delta P_{3}}{\rho}},
\end{aligned}
$$

where: $\Delta P_{1}, \Delta P_{2}, \Delta P_{3}$ - respectively the pressure drop in the cylinders; $\mu$ coefficient of consumption of working fluid; $f_{1}, f_{2}, f_{3}$ - according of the area cross-sectional of the hydraulic distributor; $\rho$ - the specific gravity of the liquid.

To calculate the dynamics of change of departure of the boom system of the manipulator we use the following output parameters: $m_{1}=350 \mathrm{~kg}, m_{2}=155 \mathrm{~kg}$, $m_{3}=65 \mathrm{~kg}, m_{4}=500 \mathrm{~kg}, l_{1}=4 \mathrm{~m}, \quad l_{2}=2 \mathrm{~m}, \quad l_{3}=0,8 \mathrm{~m}, \quad A O=1,6 \mathrm{~m}$, $O B=0,5 \mathrm{~m}, \quad C D=1,6 \mathrm{~m}, \quad D F=0,425 \mathrm{~m}, \quad F G=0,425 \mathrm{~m}, \quad E G=0,425 \mathrm{~m}$, 
$D E=0,255 \mathrm{~m}, \quad P_{n}=20 \cdot 10^{6} \mathrm{~Pa}, \quad A_{1}=0,012265 \mathrm{~m}^{2}, \quad A_{2}=0,00915 \mathrm{~m}^{2}$, $A_{3}=0.00185 \mathrm{~m}^{2}, \quad \theta_{1}=0,192 \mathrm{rad}, \quad \theta_{2}=1,378 \mathrm{rad}, \quad \theta_{3}=0,384 \mathrm{rad}$, $\theta_{4}=0,157 \mathrm{rad}, \theta_{5}=1,57 \mathrm{rad}, \rho=850 \mathrm{~kg} / \mathrm{m}^{3}$. Initial conditions of manipulator movement: $\alpha[0]=-0.3, \dot{\alpha}[0]=0, \beta[0]=-1.2, \dot{\beta}[0]=0, U_{3}[0]=1, \dot{U}_{3}[0]=0$, $v[0]=0, \dot{v}[0]=0$.

Substituting the initial parameters and initial conditions into the system of equations (10) and solving it, the graphical dependences of the kinematic and force characteristics of the manipulator with the cargo are determined and constructed (Fig. 3 - Fig. 7). The following assumptions were made when solving the equation system:

- switching time of the hydraulic distributor is $0,1 \mathrm{~s}$;

- the cross-sectional area of the hydraulic distributor varies according to linear law.

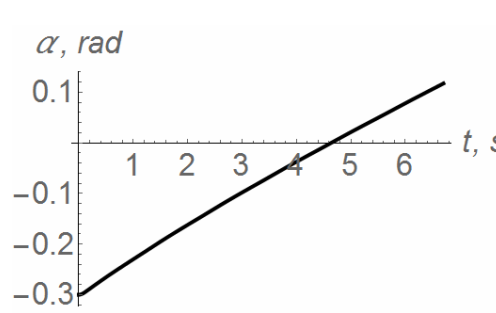

(a)

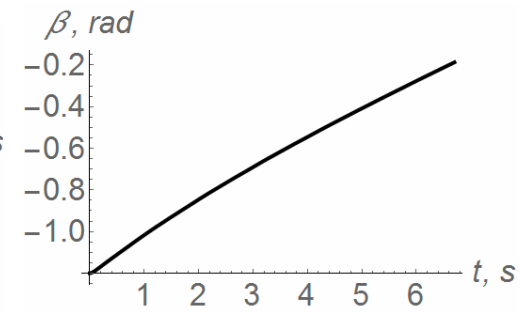

(b)

Fig. 3. Graphical dependencies of angular displacement:

(a) the first jib section; (b) the second jib section

From the system of equations (10) and expressions (11-22), the displacement of the rods of the hydraulic cylinders, respectively, of the first jib section, the second jib section, and the telescopic jib section were determined. Depending on the movement of the rod of hydraulic cylinders, the angular movement of the first jib section and the second jib section is determined. Analyzing the graphical dependences of movement of the units of the boom system (Fig. 3), it is possible to determine, in accordance with the geometric and kinematic characteristics, the functional dependence of the angular movement of the boom system units in accordance with the linear movement of the rods of hydraulic cylinders.

Having solved the system of equations with initial parameters and initial conditions, graphical dependences of speeds of movement of rods of drive hydraulic cylinders (Fig. 4) and respectively elements of the boom system (Fig. 5) were constructed with the condition of simultaneous movement of the first jib section, the second jib section, the telescopic jib section and cargo. 


\section{$U_{1}^{\prime}, \mathrm{m} / \mathrm{s}$}

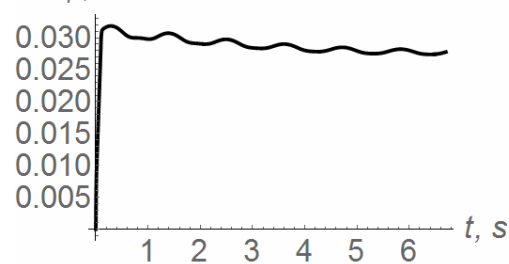

(a)

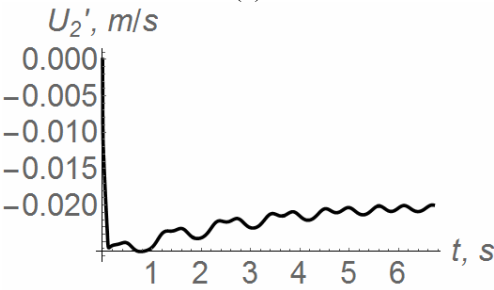

(b)

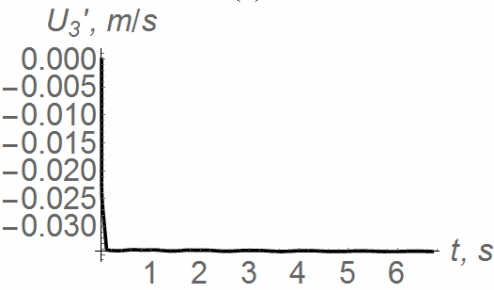

(c)

Fig. 4. Graphical dependences of speeds of movement of rods of hydraulic cylinders: (a) the first jib section; (b) the second jib section; (c) telescopic jib section
Acceleration of rod of the hydraulic cylinder of the telescopic jib section (Fig. 4(c)) occurs within $0.1 \mathrm{~s}$, which corresponds to the time of movement of the hydraulic control valve spool. The speed of movement of the rod of the hydraulic cylinder is $0.058 \mathrm{~m} / \mathrm{s}$, and with further movement is accompanied by dynamic loads.

Exit to on the steady motion of the first boom section and the second boom section (Fig. 5), occurs in accordance with of the rod steady motion of hydraulic cylinder. The angular speed of movement of the first section of the jib is $0.077 \mathrm{rad} / \mathrm{s}$, at the beginning of steady motion, with further movement has a slight decrease.

The decrease in the angular speed of movement coincides with the decrease in the linear velocity of the rod of the hydraulic cylinder (Fig. 4(a)). The angular speed of movement of the second jib section at the beginning of steady motion is 0.2 $\mathrm{rad} / \mathrm{s}$, with further movement has a slight decrease. A gradual decrease in the angular speed of the first jib section and second jib section with

steady motion, caused by the kinematic parameters of the manipulator and, accordingly, the oscillatory movement of the cargo (Fig. 7).

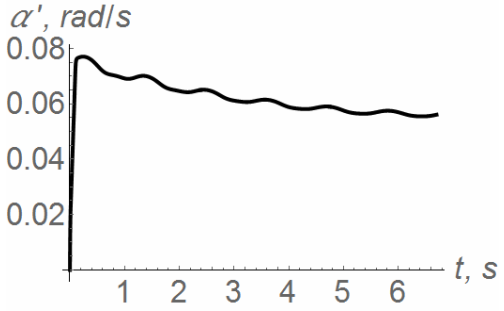

(a)

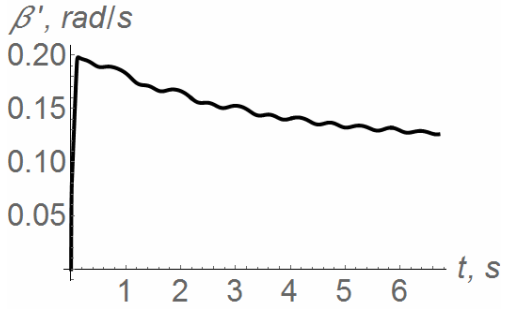

(b)

Fig. 5. Graphical dependences of the angular speed of movement of the links of the boom system: (a) the first jib section; (b) the second jib section 
As can be seen from the graphical dependencies, the pressure at the beginning of the motion is equal $2 \cdot 10^{7} \mathrm{~Pa}$, which corresponds to the pressure of the working fluid in the hydraulic system. Upon further movement of the boom system and their exit in a steady motion, the pressure in the hydraulic cylinder of the first jib section and the second jib section is equal to $5 \cdot 10^{6} \mathrm{~Pa}$, and is accompanied by dynamic loads. This is caused by the inertial component of the units of the boom system and, accordingly, the occurrence in it and the elements of the hydraulic drive of dynamic loads caused by the oscillatory movement of the cargo (Fig. 7).

Taking into account the inertial components of the units of the boom system and the fluctuations of the working fluid pressure in the hydraulic cylinders, the dependence of the cargo oscillation at the end of the jib was constructed (Fig. 7). From the graphical dependence you can see the characteristic correspondence of the deviation of the cargo from the vertical (Fig. 7), which coincides in time with the dynamic loads in the elements of the hydraulic drive (Fig. 4), links of the boom system (Fig. 5) and fluctuations in the working fluid pressure (Fig. 6).

Based on the initial conditions, there is no deviation of the cargo at the beginning of the movement. At the beginning of the steady movement of elements of the boom system (Fig. 4 - Fig. 5) the cargo deviation is maximized and equals $0,34 \mathrm{rad}$.

Such high load variability results in considerable dynamic loads in the elements of the boom system and the elements of the hydraulic drive of the manipulator. Thus reducing its

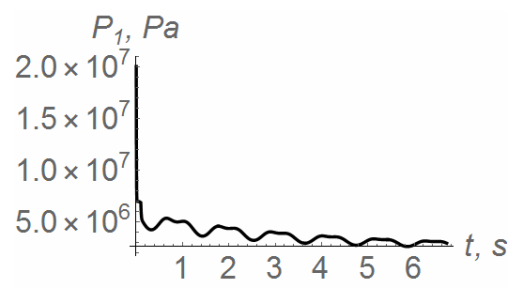

(a)

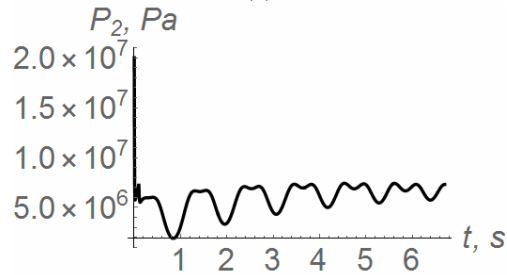

(b)

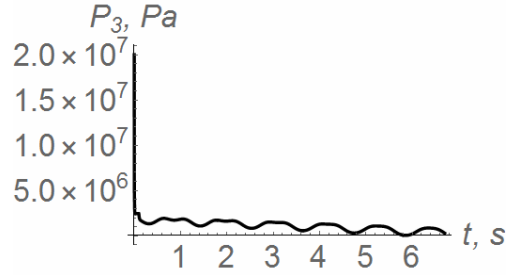

(c)

Fig. 6. Graphic dependencies of pressure change in the hydraulic cylinder: (a) the first jib section; (b) the second jib section; (c) the telescopic jib section

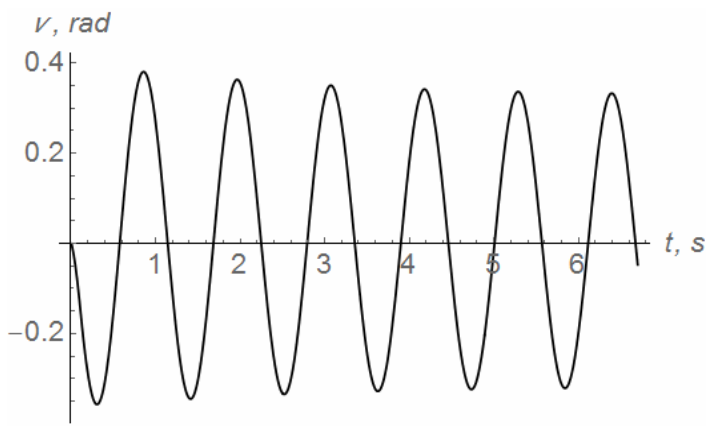

Fig. 7. Graphical dependence of the cargo oscillation 
reliability and speeding up the failure of the mechanical system as a whole.

Conclusions. As a result of the research, a mathematical model of the dynamics of change of departure in the plane of movement of the boom system of the manipulator was constructed, provided that the motions of the elements of the boom system were combined with the cargo. Dynamic analysis of the mechanism of simultaneous movement of the first jib section, the second jib section, the telescopic jib section, and the cargo oscillations is performed. Graphical dependences of dynamic loads in the boom system and elements of the hydraulic drive of the manipulator were obtained. The proposed mathematical model makes it possible to determine the actual dynamic loads in the elements of the manipulator design and drive mechanisms. The results obtained can be used in further practical design of hydraulic manipulators.

\section{REFERENCES}

1. Bashkirov V.S. O dinamicheskih nagruzkah, voznikayushih $\mathrm{v}$ gidroprivodah i metalokonstrukciyah gidromehanicheskih manipulyatorov (On dynamic loads arising in hydraulic drives and metal structures of hydromechanical manipulators) / V.S. Bashkirov, Yu.N. Dudkov, V.E. Kireev, P.B.Germanovich // Vsb.: Gidroprivod i sistemy upravleniya stroitelnyh, tyagovyh i dorozhnyh mashin. Omsk, 1980. - S. 50-55.

2. Bashkova N.V. Mestnye napryazheniya v teleskopicheskoj strele (Local stresses in telescopic jib) / N.V.Bashkova // Stroitelnye i dorozhnye mashiny. - M.: 1977. - №7 - S. 19 - 20.

3. Lovejkin V.S. Matematichna model dinamiki zmini vilotu strilovoyi sistemi krana manipulyatora (Mathematical model of dynamics change length of the crane arm system of a crane-manipulator) / V.S. Lovejkin, Yu.O. Romasevich, O.O. Spodoba // Naukovo-tehnichnij ta virobnichij zhurnal «Pidjomno transportna tehnika». - Odesa: ONPU, 2019. - № 2 (61). - S. 83-92. DOI: 10.15276/pidtt.2.61.2019.07

4. BakajB.Ya. Poperednye predstavlennya rivnyannya dinamiki manipulyatora metodom Lagranzha-Ejlera (Preliminary representation of the equation of manipulator dynamics by the Lagrange-Euler method) / B.Ya. Bakaj // Naukovij visnik NLTU Ukrayini - Lviv. Vidavnictvo NLTU Ukrayini, 2011 - Vip. 21.18. - S. 322 - 327.

5. Petrov B.A. Manipulyatory (Manipulators) / B.A. Petrov // - Leningrad. Mashinostroenie, 1984. $-238 \mathrm{~s}$.

6. Mihajlov S.I. Issledovanie dinamiki manipulyatora s uprugimi zvenyami (The study of the dynamics of a manipulator with elastic links) / S.I. Mihajlov, F.L. Chernousko // Izv.: AN SSSR. Mehanika tverdogo tela - 1984. - №2. - S. 51-58.

7. Chernousko F.L. Dinamika upravlyaemyh dvizhenij uprugogo manipulyatora (Dynamics of controlled movements of an elastic manipulator) / F.L. Chernousko // Izv.: AN SSSR. Tehnicheskaya kibernetika. - 1981. - №5. - S. 142-152.

8. Tertychnyj-Dauri V.Yu. Dinamika robototehnicheskih sistem (The dynamics of robotic systems)/ V.Yu. Tertychnyj-Dauri // - SPb.: NIU ITMO, 2012. - 128 s.

9. Berbyuk V.E. Dinamika i optimizaciya robototehnicheskih sistem (Dynamics and optimization of robotic systems) / V.E. Berbyuk // - K.: Naukova dumka, 1989. - 188 s.

10. Lovejkin V.S. Matematichna model dinamiki zmini vilotu krana manipulyatora $\mathrm{z}$ zhorstkimi lankami. (Mathematical model of dynamics of change of departure of the crane of the manipulator with rigid links ) / V.S. Lovejkin, D.O. Mishuk // Zhurnal «Tehnika budivnictva». - K.: KNUBA, 2006. - Vip. №19. - S. 26-29.

11. MishukD.O. Matematichne modelyuvannya zmini vilotu vantazhu manipulyatorom $\mathrm{z}$ gidroprivodom (Mathematical modeling of change of departure of cargo by the manipulator with the hydraulic drive) / D.O. Mishuk, V.S. Lovejkin // Girnichi, budivelni, dorozhni i meliorativni mashini. - Kiyiv. 2012. - S. 9-15.

12. Smolnikov B.A. Problemy mehaniki i optimizacii robotov (Problems of mechanics and robot optimization) / B.A. Smolnikov // - M.: Nauka, 1991. - 231 s. 
13. Zablonskij K.I. Optimalnyj sintez shem manipulyatorov promishlenyh robotov (Optimal synthesis of industrial robot manipulator circuits) / K.I. Zablonskij, N.T. Monashko, B.M. Shecin // - K.: Tehnika, 1989. - 148 s.

14. Kobrinskij A.A. Manipulyacionnye sistemy robotov (Manipulation systems of robots) / A.A. Kobrinskij, A.E. Kobrinskij // - M.: Nauka, 1985. - 343 s.

15. Lovejkin V.S. Dinamichnij analiz rolikovoyi formuvalnoyi ustanovki z krivoshipno-shatunnim prividnim mehanizmom / V.S. Lovejkin, K.I. Pochka, Yu.O. Romasevich, O.B. Pochka (Dynamic analysis of roller forming installation about a crank connecting rod the driving mechanism) // Opir materialiv i teoriya sporud: Naukovo-tehnichnij zbirnik. - Kiyiv: KNUBA, 2019. - Vip. 102. - S 91-108. https//doi.org/10.32347/2410-2547.2019.102.91-108

16. Emtyl Z.K. O vliyanie podatlivosti rabochej zhidkosti i elementov gidroprivoda na dinamicheskuyu nagruzhennost gidromanipulyatora pri sovmeshenii dvizhenij zvenev (About the effect of flexibility of the working fluid and hydraulic drive elements on the dynamic loading of the hydraulic manipulator when combining the movements of the links) / Z.K. Emtyl, N.M. Bartenev, A.P. Ta-tarenko // Trudy FORA (Fizicheskogo Obshestva Respubliki Adygeya). - Majkop: Izd-vo AGU, 2000. - № 6. S. 83-87.

17. Lagerev I.A. Dinamika trehzvennyh gidravlicheskih kranov manipulyatorov. Monografiya (Dynamics of three-link hydraulic manipulator cranes) / I.A. Lagerev A.V. Lagerev // Bryansk Izd-vo BGTU, 2012. - $196 \mathrm{~s}$.

18. Dobrachev A.A. Matematicheskoe modelirovanie dinamicheskih reakcij opor manipulyatornoj mashiny (Mathematical modeling of the dynamic reactions of the supports of a manipulator machine) / A.A. Dobrachev, L.T. Raevskaya, A.V. Shvec // Vestnik mashinostroeniya. - 2010. - №1 - s. 17-20.

19. Raevskaya L.T. Isledovanie linejnyh i uglovyh skorostej zvenev manipulyatora (The study of linear and angular velocities of the links of the manipulator) / L.T. Raevskaya, A.V. Shvec, Dahiev F.F. // Vestnik mashinostroeniya. - 2012. - №10 - S. 26-28.

Стаття надійшла до редакиї 10.12.2019 р.

Ловейкін В.С., Ромасевич Ю.О., Сподоба О.О., Ловейкін А.В., Почка К.І.

\section{МАТЕМАТИЧНА МОДЕЛЬ ДИНАМІКИ ЗМІНИ ВИЛЬОТУ СТРІЛОВОЇ СИСТЕМИ МАНІПУЛЯТОРА ЗА ОДНОЧАСНОГО ПЕРЕМНЩЕННЯ ЇЇ ЛАНОК}

3 метою підвищення продуктивності та надійності маніпулятора згідно 3 нормативнотехнічною документацією, яка регламентує безпечну експлуатацію маніпуляторів допускається суміщення рухів 3 одночасним переміщенням декількох ланок стрілової системи. В результаті в роботі розглянута методика побудови математичної моделі в площині зміни вильоту стрілової системи маніпулятора із вантажем. Математична модель побудована iз врахуванням трьох одночасних рухів, а саме, одночасного переміщення першої секції стріли, другої секції стріли, телескопічної секції стріли та коливання вантажу. Розраховано функції зміни кінематичних та динамічних характеристик стрілової системи за одночасного переміщення іiі ланок. Побудова математичної моделі виконана із застосуванням рівнянь Лагранжа другого роду. При цьому за узагальнені координати моделі маніпулятора прийнято, кутові координати положення ланок стрілової системи та кутове відхилення від вертикалі вантажу. А механічні характеристики гідравлічного приводу, представлені у вигляді квадратичних залежностей між діючими зусиллями та швидкостями переміщень штоків гідроциліндрів. Керування елементами приводу представлено у вигляді рівнянь витрати робочої рідини зі зміною площі прохідного перерізу гідравлічного розподільника за лінійним законом. В результаті отримано рівняння руху маніпулятора з врахуванням впливу інерційної складової кожної ланки стрілової системи та впливу коливань вантажу на динамічні навантаження елементів металоконструкції та елементів гідравлічного приводу. Розроблена математична модель дозволяє теоретично визначити вплив одночасного переміщення першої секції стріли, другої секції стріли та телескопічної секції стріли на коливання вантажу, а також вплив коливання вантажу на динамічні навантаження, які при цьому виникають в стріловій системі та елементах гідравлічного приводу маніпулятора.

Ключові слова: математична модель, зміна вильоту, суміщення рухів, маніпулятор, рівняння Лагранжа другого роду, динамічні навантаження, коливання вантажу. 


\section{Loveikin V.S., Romasevich Yu.O., Spodoba O.O. Loveikin A.V., Pochka K.I.,}

\section{MATHEMATICAL MODEL OF THE DYNAMICS CHANGE DEPARTURE OF THE JIB SYSTEM MANIPULATOR WITH THE SIMULTANEOUS MOVEMENT OF ITS LINKS}

In order to increase the productivity and reliability of the manipulator according to the normative and technical documentation, which regulates the safe operation of the manipulators, it is allowed to combine movements with the simultaneous movement of several elements of the boom system. As a result, the paper methodology reviewed for constructing a mathematical model in the plane of the departure change of the boom system of a manipulator with a load. The mathematical model is constructed from the calculation of three simultaneous movements, namely, the simultaneous movement of the first jib section, the second jib section, the telescopic jib section and the oscillation of the cargo. The functions of changing the kinematic and dynamic characteristics of the boom system with the simultaneous movement of its links are calculated. The construction of a mathematical model is carried out using Lagrange equations of the second kind. Moreover, the generalized coordinates of the manipulator model are taken as the angular coordinates of the position of the links of the boom system and the angular deviation from the vertical of the cargo. And the mechanical characteristics of the hydraulic drive are presented in the form of square dependencies between the acting forces and the speeds of movement of the hydraulic cylinder rods. The control of the drive elements is presented in the form of equations of the flow rate of the working fluid with a change in the area of the flow crosssection of the hydraulic distributor according to a linear law. As a result, the equation of motion of the manipulator is obtained, taking into account the influence of the inertial component of each link of the boom system and the influence of cargo oscillations on the dynamic loads of metalware elements and hydraulic drive elements. The developed mathematical model allows one to theoretically determine the effect of simultaneous movement of the first jib section, the second jib section and the telescopic jib section on cargo oscillation, as well as the effect of cargo oscillation on dynamic loads that occur in the boom system and manipulator hydraulic drive elements.

Keywords: mathematical model, varying the radius, combination of movements, manipulator, Lagrange equations of the second kind, dynamic loads, load oscillations.

\section{Ловейкин В.С., Ромасевич Ю.А., Сподоба А.А., Ловейкин А.В., Почка К.И. \\ МАТЕМАТИЧЕСКАЯ МОДЕЛЬ ДИНАМИКИ ИЗМЕНЕНИЯ ВЫЛЕТА СТРЕЛОВОЙ СИСТЕМЫ МАНИПУЛЯТОРА ПРИ ОДНОВРЕМЕННОМ ПЕРЕМЕЩЕНИИ ЕЕ ЗВЕНЬEB}

С целью повышения производительности и надежности манипулятора согласно нормативно-технической документации, которая регламентирует безопасную эксплуатацию манипуляторов, допускается совмещение движений с одновременным перемещением нескольких элементов стреловой системы. В результате в работе рассмотрена методика построения математической модели в плоскости изменения вылета стреловой системы манипулятора с грузом. Математическая модель построена из расчета трех одновременных движений, а именно, одновременного перемещения первой секции стрелы, второй секции стрелы, телескопической секции стрелы и колебания груза. Рассчитаны функции изменения кинематических и динамических характеристик стреловой системы при одновременном перемещении ее звеньев. Построение математической модели проводится с использованием уравнений Лагранжа второго рода. При этом за обобщенные координаты модели манипулятора принято, угловые координаты положения звеньев стреловой системы и углового отклонения от вертикали груза. А механические характеристики гидравлического привода, представлены в виде квадратных зависимостей между действующими усилиями и скоростями перемещения штоков гидроцилиндров. Управление элементами привода представлено в виде уравнений расхода рабочей жидкости со сменой площадью проходного сечения гидравлического распределителя за линейным законом. В результате получено уравнение движения манипулятора с учетом влияния инерционной составляющей каждого звена стреловой системы и влияния колебаний груза на динамические нагрузки элементов металлоконструкции и элементов гидравлического привода. Разработанная математическая модель позволяет теоретически определить влияние одновременного перемещения первой секции стрелы, второй секции стрелы и телескопической секции стрелы на колебания груза, а также влияние колебаний груза на динамические нагрузки, которые при этом возникают в стреловой системе и элементах гидравлического привода манипулятора.

Ключевые слова: математическая модель, изменение вылета, совмещение движений, манипулятор, уравнение Лагранжа второго рода, динамические нагрузки, колебания груза. 
УДК 621.87

Ловейкін В.С., Ромасевич Ю.О., Сподоба О.О., Ловейкін А.В., Почка К.І. Математична модель динаміки зміни вильоту стрілової системи маніпулятора за одночасного переміщення їі ланок // Опір матеріалів та теорія споруд: Наук.-техн. збірник. - К.: КНУБА, 2020. - Вип. 104. - С. 175-190.

Отримано рівняння руху маніпулятора з врахуванням впливу інериійної складової кожної ланки стрілової системи та впливу коливань вантажу на динамічні навантаження елементів металоконструкиї та елементів гідравлічного приводу. Встановлено вплив одночасного переміщення першої секиї стріли, другої секиії стріли та телескопічної секиії стріли на коливання вантажу, а також вплив коливання вантажу на динамічні навантаження, які при иьому виникають в стріловій системі та елементах гідравлічного приводу маніпулятора.

Іл. 7. Бібліогр. 19 назв.

\section{UDC 621.87}

Loveikin V.S., Romasevich Yu.O., Spodoba O.O. Loveikin A.V., Pochka K.I. Mathematical model of the dynamics change departure of the jib system manipulator with the simultaneous movement of its links // Strength of Materials and Theory of Structures: Scientific-and-technical collected articles. - K.: KNUBA, 2020. - Issue 104. - P. 175-190.

An equation of motion of the manipulator is obtained taking into account the influence of the inertial component of each link of the boom system and the effect of the oscillatory movement of the cargo on the dynamic loads of the metalware elements and hydraulic drive elements. The influence of the simultaneous movement of the first jib section, the second jib section and the telescopic jib section on cargo oscillation, as well as the effect of cargo oscillation on dynamic loads that occur in the boom system and manipulator hydraulic drive elements, is determined.

Fig. 7. Ref. 19.

\section{УДК 621.87}

Ловейкин В.С., Ромасевич Ю.А., Сподоба А.А., Ловейкин А.В., Почка К.И. Математическая модель динамики изменения вылета стреловой системы манипулятора при одновременном перемещении ее звеньев // Сопротивление материалов и теория сооружений. - 2020. - Вып. 104. - С. 175-190.

Получено уравнение движения манипулятора с учетом воздействия инериионной составляющей каждого звена стреловой системы и воздействия колебательного движения груза на динамические нагрузки элементов металлоконструкиии и элементов гидравлического привода. Определено влияние одновременного перемещения первой секции стрель, второй секиии стрелы и телескопической секции стрелы на колебания груза, а также воздействие колебаний груза на динамические нагрузки, которые при этом возникают в стреловой системе и элементах гидравлического привода манипулятора.

Ил. 7. Библиогр. 19 назв. 
Автор (вчена ступень, вчене звання, посада): доктор технічних наук, професор, завідувач кафедри конструювання машин і обладнання Наџіонального університету біоресурсів $i$ природокористування Украӥни ЛОВЕЙКІН Вячеслав Сергійович

Адреса робоча: 03041, Украӥна, м. Київ, вул. Героӥв Оборони, 12, навчальний корпус № 11, Національний університет біоресурсів $i$ природокористування Украӥни, кафедра конструювання машин і обладнання, ЛОВЕЙКІНУ Вячеславу Сергійовичу

Робочий тел.: +38(044) 527-87-34;

Мобільний тел.: +38(097) 349-14-53;

E-mail: lovvs@ukr.net

ORCID ID: https://orcid.org/0000-0003-4259-3900

Автор (вчена ступень, вчене звання, посада): доктор технічних наук, дочент, професор кафедри конструювання машин і обладнання Наџіонального університету біоресурсів $i$ природокористування України РОМАСЕВИЧ Юрій Олександрович

Адреса робоча: 03041, Украӥна, м. Київ, вул. Героїв Оборони, 12, навчальний корпус № 11, Національний університет біоресурсів $і$ природокористування України, кафедра конструювання машин і обладнання, РОМАСЕВИЧУ Юрію Олександровичу

Робочий тел.: +38(044) 527-87-34;

Мобільний тел.: +38(068) 102-31-64;

E-mail: romasevichyuriy@ukr.net

ORCID ID: https://orcid.org/0000-0001-5069-5929

Автор (вчена ступень, вчене звання, посада): аспірант кафедри конструювання машин $i$ обладнання Національного університету біоресурсів $і$ природокористування Украӥни СПОДОБА Олександр Олексійович

Адреса робоча: 03041, Украӥна, м. Київ, вул. Героїв Оборони, 12, навчальний корпус № 11, Національний університет біоресурсів $і$ природокористування Украӥни, кафедра конструювання машин і обладнання, СПОДОБІ Олександру Олексійовичу

Мобільний тел.: +38(067) 804-21-71;

E-mail: sp1309@ukr.net

ORCID ID: https://orcid.org/0000-0001-8217-866X

Автор (вчена ступень, вчене звання, посада): кандидат фізико-математичних наук, доцент кафедри математичної фізики Київського національного університету імені Тараса Шевченка ЛОВЕЙКІН Андрій Вячеславович

Адреса робоча: 03022, Украӥна, м. Київ, проспект академіка Глушкова, 4е ,корпус механікоматематичного факультету, Київький національний університет імені Тараса Шевченка, кафедра математичної фізики, ЛОВЕЙКІНУ Андрію Вячеславовичу

Мобільний тел.: +38(097) 350-91-23;

E-mail: anlov74@gmail.com

ORCID ID: https://orcid.org/0000-0002-7988-8350

Автор (вчена ступень, вчене звання, посада): доктор технічних наук, доцент, завідувач кафедри професійної освіти КНУБА ПОЧКА Костянтин Іванович

Адреса робоча: 03037, Украӥна, м. Київ, Повітрофлотський проспект 31, Київський національний університет будівництва $і$ архітектури, кафедра основ професійного навчання, ПОЧЦІ Костянтину Івановичу

Робочий тел.: +38(044) 248-69-25;

Мобільний тел.: +38(097) 212-86-29;

E-mail: shanovniy@ukr.net

ORCID ID: https://orcid.org/0000-0002-0355-002X 